\title{
PERBANDINGAN MODEL PEMBELAJARAN CORE DENGAN DISCOVERY LEARNING DALAM PEMBELAJARAN MATEMATIKA TERHADAP KEMAMPUAN PEMECAHAN MASALAH MATEMATIS DAN SELF-REGULATED LEARNING SISWA SMA
}

\author{
Risa Mulyanto Putri ${ }^{1}$, Wisma Eliarti ${ }^{2}$ \\ ${ }^{1,2}$ Universitas Pasundan \\ $\underline{1 \text { risamulyantoputri@gmail.com, }}{ }^{2}$ wismaeliyartipmat@unpas.ac.id
}

\begin{abstract}
Abstrak
Pada pembelajaran menggunakan model Discovery Learning terlihat bahwa interaksi antar siswa masih kurang. Selama proses diskusi, sebagian besar kelompok belum melibatkan setiap anggotanya karena anggotanya mengerjakan LKS secara individu. Akibatnya, ketika dihadapkan pada persoalan matematika siswa kurang mampu untuk menyelesaikannya. Salah satu upaya untuk mengatasi masalah tersebut adalah dengan menggunakan model pembelajaran inovatif lainnya. Salah satunya dengan penggunaan model CORE (Connecting, Organizing, Reflecting, dan Extending). CORE merupakan model pembelajaran dengan metode diskusi dengan menghubungkan informasi lama dengan informasi baru, mengorganisasikan sejumlah materi yang bervariasi, merefleksikan segala sesuatu yang peserta didik pelajari, dan mengembangkan lingkungan belajar. Tujuan dari penelitian ini adalah membandingkan kemampuan pemecahan masalah matematis dan Self-Regulated Learning siswa yang menggunakan model CORE dengan siswa yang menggunakan model Discovery Learning. Metode penelitian yang digunakan adalah kuantitatif eksperimen, dengan desain kuasi eksperimen. Populasi dalam penelitian ini adalah seluruh siswa SMAN 13 Bandung. Dua dari tiga belas kelas XI yang ada dipilih sebagai sampel penelitian. Instrumen yang digunakan adalah tes dan angket. Analisis data yang digunakan adalah uji kesamaan dua rerata dengan uji-t dua pihak menggunakan Independent Sample TTest. Berdasarkan analisis pada keseluruhan tahapan penelitian dapat disimmpulkan bahwa: 1) Kemampuan pemecahan masalah matematis siswa SMA yang memperoleh model pembelajaran CORE tidak lebih baik dari kemampuan pemecahan masalah matematis siswa SMA yang memperoleh model pembelajaran Discovery Learning, 2) Self-Regulated Learning siswa yang dalam pembelajaran matematikanya menggunakan model pembelajaran CORE lebih baik daripada siswa yang menggunakan model pembelajaran Discovery Learning.
\end{abstract}

Kata Kunci : CORE, Discovery Learning, Model Pembelajaran, Pemecahan Masalah Matematis, SelfRegulated Learning.

\begin{abstract}
In the implementation of learning process using Discovery Learning shows that interaction between students is still very low. During the discussion process, most groups haven't involved each member because they are working on individual, so the discussion is dominated only by some students. As a result, when given a mathematical problem, students are unable to solve it. One attempt to solve the problem is using other innovative learning models. One of the solutions is using CORE (Connecting, Organizing, Reflecting, and Extending) a learning model with a discussion method by connecting old information with new information, organizing several information, reflecting on everything that students learn, and extending environment of learning. The purpose of this research is to examine the differences in mathematical problem solving skills and Self-Regulated Learning students using the CORE and Discovery Learning in mathematical learning. The research method is quantitative experiments, with quasi experimental design. Population that used in this research is all student of Senior High School 13 Bandung. Two of thirteen existing XI classes were selected as research samples. The instruments are tests and questionnaires. Data analysis is used two-equation test with two-tailed test using Independent Sample T-Test. Based on the analysis of the research can be concluded that: 1)The ability of mathematical problem solving of high school students who get the CORE learning model isn't better than students who get the Discovery Learning, 2)Self-Regulated Learning students in the learning mathematics using the CORE learning model is better than the students using the Discovery Learning model.
\end{abstract}

Keywords: CORE, Discovery Learning, Learning Model, Mathematical Problem Solving, Self-Regulated Learning. 


\section{PENDAHULUAN}

\section{Latar Belakang Masalah}

Matematika merupakan mata pelajaran yang berperan disegala bidang kehidupan, oleh karena itulah mengapa matematika diajarkan diberbagai jenis jenjang pendidikan. Pembelajaran matematika sendiri memiliki beberapa tujuan salah satunya adalah agar siswa memiliki kemampuan memecahkan masalah yang meliputi kemampuan memahami masalah, merancang model matematika, menyelesaikan model dan menafsirkan solusi yang diperoleh (Depdiknas, 2006). Kemampuan pemecahan masalah tersebut diperlukan untuk mencapai tujuan kurikulum 2013 yakni agar siswa memiliki kemampuan hidup sebagai pribadi dan warga negara yang beriman, produktif, kreatif, inovatif dan afektif serta mampu berkontribusi pada kehidupan bermasyarakat, berbangsa, bernegara dan peradaban dunia.

Kemampuan berpikir untuk pemecahan masalah matematis adalah bagian yang sangat penting. Namun, kenyataannya di lapangan kemampuan pemecahan masalah matematik siswa masih rendah (Satriani dkk., 2015, hlm. 3). Andriatna (2012, hlm. 20) mengungkapkan bahwa berdasarkan hasil dialog dengan pengajar matematika dan pengalaman mengajar di sekolah menunjukan bahwa siswa masih merasa kesulitan dalam menyelesaikan soal-soal rutin apalagi dalam kemampuan pemecahan masalah matematisnya. Berdasarkan wawancara dengan beberapa guru matematika SMA, diperoleh informasi bahwa siswa masih belum terbiasa dengan soal-soal pemecahan masalah dan umumnya mereka kurang mampu dalam menuliskan penyelesaiannya.

Para ahli pendidikan sudah banyak menemukan berbagai macam model pembelajaran yang diterapkan dalam proses pembelajaran. Dengan adanya model pembelajaran, guru mendapatkan beragam alternatif cara untuk menyampaikan informasi kepada siswa (Wahab, 2007, hlm. 10). Pembelajaran pada kurikulum 2013 menggunakan pendekatan saintifikyang dimaksudkan agar peserta didik aktif dalam proses mencari informasi, mengenal dan memahami materi menggunakan pendekatan ilmiah. Salah satu model yang banyak digunakan adalah Discovery Learning. Dalam pelaksanaannya, guru berperan sebagai pembimbing dengan memberikan kesempatan kepada siswa untuk belajar secara aktif, sebagaimana pendapat guru harus dapat membimbing dan mengarahkan kegiatan belajar siswa sesuai dengan tujuan (Sadirman, 2005, hlm. 145). Guru memberi stimulus pada awal pembelajaran. Setelah itu guru membagi siswa dalam kelompokkelompok. Guru membagikan LKS (Lembar Kerja Siswa) kepada setiap kelompok untuk didiskusikan. Selama proses diskusi, sebagian besar kelompok mengerjakan LKS secara individu. Selain itu, diskusi pada beberapa kelompok juga belum melibatkan setiap anggotanya. Akibatnya, ketika dihadapkan dengan persoalan matematika siswa kurang mampu untuk menyelesaikannya.

Selain dari model pembelajaran yang disarankan dalam kurikulum 2013, masih banyak model pembelajaran inovatif untuk mendukung pembelajaran salah satunya adalah CORE (Connecting, Organizing, Reflecting dan Extending) yang merupakan model pembelajaran dengan metode diskusi. Menurut Harmsem (Yumiati, 2015, hlm. 9), elemenelemen tersebut digunakan untuk menghubungkan informasi lama dengan informasi baru, mengorganisasikan sejumlah materi yang bervariasi, merefleksikan segala sesuatu yang peserta didik pelajari dan mengembangkan lingkungan belajar.

Dapat dilihat bahwa untuk mengetahui kemampuan siswa dalam memecahkan masalah dalam pembelajaran matematika berkaitan dengan cara belajar mereka. Konsep Self-Regulated Learning merupakan salah satu konsep penting dalam teori belajar sosial. Menurut Pintrich (1990) Self-Regulated Learning adalah cara belajar siswa aktif secara individu untuk mencapai tujuan akademik dengan cara pengontrolan perilaku, memotivasi diri sendiri dan menggunakan kognitifnya dalam belajar. 
Oleh karena itu dengan menggunakan model pembelajaran selain model Discovery Learning, dalam hal ini penggunaan model pembelajaran CORE diharapkan dapat mempengaruhi kemampuan pemecahan masalah matematis dan Self-Regulated Learning siswa. Tulisan ini mengangkat mengenai, "Perbandingan Model Pembelajaran CORE (Connecting, Organizing, Reflecting and Extending) dan Discovery Learning dalam Pembelajaran Matematika terhadap Kemampuan Pemecahan Masalah Matematis dan SelfRegulated Learning Siswa SMA".

\section{Rumusan Masalah}

Berdasarkan latar belakang masalah di atas, maka rumusan masalah pada penelitian ini adalah sebagai berikut: (1) Adakah perbedaan kemampuan pemecahan masalah matematis siswa yang menggunakan model pembelajaran CORE (Connecting, Organizing, Reflecting and Extending) dibandingkan dengan siswa yang menggunakan model pembelajaran Discovery Learning dalam pembelajaran matematika? (2) Adakah perbedaan Self-Regulated Learning siswa yang menggunakan model pembelajaran CORE (Connecting, Organizing, Reflecting and Extending) dibandingkan dengan siswa yang menggunakan model pembelajaran Discovery Learning dalam pembelajaran matematika?

\section{Tujuan Penelitian}

Berdasarkan rumusan masalah di atas, maka tujuan penelitian ini adalah sebagai berikut: (1) Mengkaji perbedaan kemampuan pemecahan masalah matematis siswa yang menggunakan model pembelajaran CORE dengan siswa yang menggunakan model pembelajaran Discovery Learning dalam pembelajaran matematika. (2) Menganalisis perbedaan Self-Regulated Learning siswa yang menggunakan model pembelajaran CORE dengan siswa yang menggunakan model pembelajaran Discovery Learning dalam pembelajaran matematika.

\section{Manfaat Penelitian}

Hasil penelitian ini diharapkan dapat memberikan manfaat kepada berbagai pihak, diantaranya: (1) Secara teoretis, penelitian ini dapat memberi sumbangan pada perkembangan ilmu pendidikan, khususnya pada penerapan model pembelajaran untuk mengembangkan kemampuan pemecahan masalah matematis dan Self-Regulated Learning siswa. (2) Secara praktis manfaat yang dapat diberikan dari hasil penelitian ini diantaranya:

a. Bagi siswa, dalam penelitian ini siswa dapat berlatih menyelesaikan soal-soal yang berkaitan dengan kemampuan pemecahan masalah matematis yang akan berguna dalam kehidupan sehari-hari.

b. Bagi guru, penelitian ini dapat memberikan pemahaman kepada guru tentang model pembelajaran CORE dapat menjadi salah satu alternatif model pembelajaran yang dapat dipilih dalam proses pembelajaran untuk melatih kemampuan pemecahan masalah matematis dan Self-Regulated Learning siswa.

c. Bagi sekolah, menjadikan masukan bagi pengembang kurikulum di sekolah.

d. Bagi peneliti, dapat menambah pengetahuan dan pengalaman pembelajaran matematika dengan menggunakan model pembelajaran CORE dan Discovery Learning dalam upaya mengembangkan kemampuan pemecahan masalah matematis dan Self-Regulated Learning siswa.

e. Bagi peneliti selanjutnya, dapat melanjutkan serta mengembangkan penelitian yang lebih luas dari penelitian sebelumnya. 


\section{Kajian Teori}

\section{Kemampuan Pemecahan Masalah Matematis}

Pemecahan masalah adalah suatu proses atau upaya individu untuk merespon atau mengatasi halangan atau kendala ketika suatu jawaban atau metode jawaban belum tampak jelas. Pemecahan masalah diartikan sebagai usaha sadar untuk mencari jalan keluar dari suatu kesulitan, tetapi tujuan tersebut tidak segera dapat dicapai (Polya, 1981). Pemecahan masalah merupakan salah satu bagian dari tujuan pembelajaran matematika yang sangat penting dalam proses pembelajaran, karena siswa dimungkinkan memperoleh pengalaman menggunakan pengetahuan serta keterampilan yang sudah dimiliki untuk diterapkan pada memecahkan masalah yang bersifat non rutin, karena melalui kegiatan ini aspek-aspek kemampuan matematika seperti aturan pada masalah non rutin, penemuan pola, penggeneralisasian dan komunikasi matematika dapat dikembangkan secara lebih baik. Berdasarkan pendapat-pendapat diatas, kemampuan pemecahan masalah matematika adalah suatu kesanggupan untuk menyelesaikan atau memecahkan masalah menggunakan pengetahuan matematika melalui tahap-tahap pemecahan masalah.

\section{Self-Regulated Learning}

Zimmerman (Woolfolk, 2004) mengatakan bahwa Self-Regulation merupakan sebuah proses dimana seseorang peserta didik mengaktifkan dan menopang kognisi, perilaku dan perasaannya yang secara sistematis berorientasi pada pencapaian suatu tujuan. Ketika tujuan tersebut meliputi pengetahuan maka yang dibicarakan adalah Self-Regulated Learning. Self-Regulated Learning dapat berlangsung apabila peserta didik secara sistematis mengarahkan perilakunya dan kognisinya dengan cara memberi perhatian pada instruksiinstruksi, tugas-tugas, melakukan proses dan menginterpretasikan pengetahuan, mengulangulang informasi untuk mengingatnya serta mengembangkan dan memelihara keyakinannya positif tentang kemampuan belajar dan mampu mengantisipasi hasil belajarnya. Dari uraian di atas maka dapat disimpulkan bahwa Self-Regulated Learning adalah proses bagaimana seorang peserta didik mengatur pembelajarannya sendiri dengan mengaktifkan kognitif, afektif dan perilakunya sehingga tercapai tujuan belajar. Peneliti menyimpulkan bahwa definisi Self-Regulated Learning adalah kemampuan siswa dalam proses belajar untuk memonitor, meregulasi dan mengontrol kognisi, motivasi dan perilaku yang kemudian semuanya diarahkan dan didorong oleh tujuan serta mengutamakan konteks lingkungan.

\section{Model Pembelajaran CORE}

CORE merupakan singkatan dari Connecting, Organizing, Reflecting dan Extending. Menurut Harmsem dalam (Yumiati, 2015, hlm. 9), elemen-elemen tersebut digunakan untuk menghubungkan informasi lama dengan informasi baru, mengorganisasikan sejumlah materi yang bervariasi, merefleksikan segala sesuatu yang peserta didik pelajari dan mengembangkan lingkungan belajar. Calfee (2010, hlm.133) juga mengungkapkan bahwa yang dimaksud pembelajaran model CORE adalah model pembelajaran yang mengharapkan siswa untuk dapat mengkonstruksi pengetahuannya sendiri dengan cara menghubungkan (Connecting) dan mengorganisasikan (Organizing) pengetahuan baru dengan pengetahuan lama kemudian memikirkan kembali konsep yang sedang dipelajari (Reflecting) serta diharapkan siswa dapat memperluas pengetahuan mereka selama proses belajar mengajar berlangsung (Extending).

\section{Model Pembelajaran Discovery Learning}

Model pembelajaran yang digunakan disini sesuai dengan kurikulum 2013 menggunakan model pembelajaran Discovery Learning. Model ini menekankan pentingnya 
pemahaman struktur atau ide-ide penting terhadap suatu disiplin ilmu, melalui keterlibatan siswa secara aktif dalam proses pembelajaran (Hosnan, 2014, hlm. 280). Agus N. Cahyo, (2013, hlm. 100) mengatakan "Discovery Learning adalah metode mengajar yang mengatur pengejaran sedemikian rupa sehingga anak memperoleh pengetahuan yang sebelumnya belum diketahuinya tidak melalui pemberitahuan, tetapi menemukan sendiri. Menurut Oemar Hamalik (2002, hlm. 134), Metode Discovery Learning adalah suatu prosedur mengajar yang menitikberatkan studi individual, manipulasi objek-objek dan eksperimentasi oleh siswa sebelum membuat generalisasi sampai siswa menyadari suatu konsep. Dari beberapa pengertian di atas dapat disimpulkan bahwa Discovery Learning (penemuan terbimbing) adalah model pembelajaran yang dirancang agar siswa dapat menemukan konsep-konsep pembelajaran melalui proses pengamatannya sendiri.

\section{METODE PENELITIAN}

Metode yang digunakan dalam penelitian ini adalah metode penelitian kuantitatif. Desain penelitian yang digunakan adalah kuasi eksperimen di mana subjek tidak dikelompokan secara acak tetapi menerima keadaan subjek apa adanya (Russeffendi, 2010, hlm. 52). Variabel bebas yang digunakan dalam penelitian ini adalah penggunaan model pembelajaran CORE dan Discovery Learning. Variabel terikat yang digunakan dalam penelitian ini adalah kemampuan pemecahan masalah matematis dan Self-Regulated Learning siswa. Pada penelitian ini hanya melibatkan dua kelompok, kelompok eksperimen 1 memperoleh pengajaran matematika dengan model pembelajaran CORE sebagai perlakuan dan kelompok eksperimen 2 memperoleh pengajaran matematika dengan model pembelajaran Discovery Learning sebagai perlakuan. Kedua kelompok tersebut memperoleh soal (pretest-posttest) matematika yang serupa. Populasi dalam penelitian ini adalah siswa SMAN 13 Bandung. Dipilih dua kelas yaitu kelas XI MIPA 7 sebagai kelas eksperimen 1 dan kelas XI MIPA 6 sebagai kelas eksperimen 2. Teknik pengumpulan data yang digunakan dalam penelitian ini berupa tes kemampuan pemecahan masalah dan angket Self-Regulated Learning.

\section{HASIL DAN PEMBAHASAN}

\section{Kemampuan Pemecahan Masalah Matematis}

Data hasil penelitian yang berhasil dikumpulkan adalah data skor pretest dan data skor posttest. Data tersebut kemudian dianalisis untuk mengetahui ketercapaiannya. Pada penelitian ini taraf kepercayaan yang digunakan adalah 95\% atau $\alpha=5 \%$. Secara sekilas skor rata-rata pretest dan postest dapat dilihat dalam tabel 1 berikut.

Tabel 1. Persentase Sampel Penelitian

\begin{tabular}{lcc}
\hline Kelas & $\overline{\boldsymbol{x}}$ Pretest & $\overline{\boldsymbol{x}}$ Posttest \\
\hline Eksperimen 1 & 11,125 & 47,5 \\
Eksperimen 2 & 12,485 & 47,6 \\
\hline
\end{tabular}

Berdasarkan analisis data hasil tes akhir (posttest) yang telah dilakukan, dapat dilihat bahwa skor rata-rata kemampuan pemecahan masalah pada kelas eksperimen 1 yang menggunakan model pembelajaran CORE lebih rendah namun tidak berbeda jauh dibandingkan dengan kelas eksperimen 2 yang menggunakan model pembelajaran Discovery Learning. Data tersebut kemudian diuji normalitas dan homogenitasnya. Hasil analisis menunjukkan bahwa kedua kelas berdistribusi normal dan homogen.

Selanjutnya dilakukan uji kesamaan dua rerata dengan uji-t dua pihak menggunakan Independent Sample T-Test. Hipotesisnya dirumuskan dalam bentuk hipotesis statistik (uji pihak kanan) menurut Sugiyono (2016, hlm. 121) sebagai berikut: 
$\mathrm{H}_{0}: \mu_{1} \leq \mu_{2}$

$\mathrm{H}_{\mathrm{a}}: \mu_{1}>\mu_{2}$

Perumusan hipotesis komparatifnya sebagai berikut:

$\mathrm{H}_{0}$ : Kemampuan pemecahan masalah matematis siswa yang menggunakan model pembelajaran CORE (Connecting, Organizing, Reflecting and Extending) tidak lebih baik dibandingkan dengan siswa yang menggunakan model pembelajaran Discovery Learning dalam pembelajaran matematika.

$\mathrm{H}_{\mathrm{a}}$ : Kemampuan pemecahan masalah matematis siswa yang menggunakan model pembelajaran CORE (Connecting, Organizing, Reflecting and Extending) lebih baik dibandingkan dengan siswa yang menggunakan model pembelajaran Discovery Learning dalam pembelajaran matematika.

Setelah dilakukan pengolahan data, tampilan data dapat dilihat pada Tabel 2.

\section{Tabel 2. Uji-t Kemapuan Pemecahan Masalah Matematis}

\begin{tabular}{cccc}
\hline & \multicolumn{3}{c}{ t-test for Equality of Means } \\
\cline { 2 - 4 } & $\mathrm{T}$ & $\mathrm{df}$ & Sig. (2-tailed) \\
\hline Equal variances assumed & .226 & 62 & .822 \\
\hline
\end{tabular}

Pada Tabel 2 nilai signifikasi 2-tailed $=0,828$. Menurut Uyanto (2006, hlm. 120), "Karena kita melakukan uji hipotesis satu pihak, maka nilai $p$-value (2-tailed) harus dibagi dua", sehingga menjadi $\frac{0,828}{2}=0,414$. Karena $p$-value $=0,414>\alpha=0,05$ maka $\mathrm{H}_{0}$ diterima dan $\mathrm{H}_{\mathrm{a}}$ ditolak. Hal ini juga terlihat pada Gambar 1.

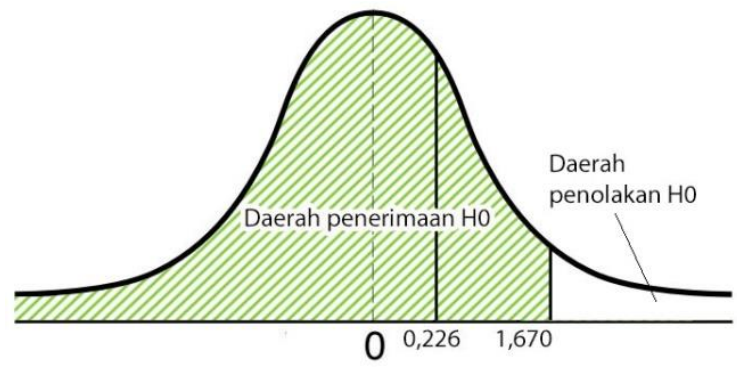

Gambar 1. Uji Satu Pihak Kemampuan Pemecahan Masalah Matematis

Pada Gambar 1 dengan nilai $d f=62$ dan taraf kesalahan $(\alpha)$ ditetapkan 5\% terlihat bahwa $t_{\text {hitung }} \leq t_{\text {tabel }}(0,226 \leq 1,670)$, nilai $t_{\text {hitung }}$ berada pada daerah penerimaan $\mathrm{H}_{0}$, maka $\mathrm{H}_{0}$ diterima dan $\mathrm{H}_{\mathrm{a}}$ ditolak sehingga dapat disimpulkan bahwa kemampuan pemecahan masalah matematis siswa SMA yang memperoleh model pembelajaran CORE tidak lebih baik dari kemampuan pemecahan masalah matematis siswa SMA yang memperoleh model pembelajaran Discovery Learning.

Walaupun ini tidak sesuai dengan hipoteis yang disusun oleh peneliti, kemampuan pemecahan masalah matematis siswa dikedua kelas tidak berbeda secara signifikan. Hal ini disebabkan oleh perbedaan perlakuan pada kedua kelas saat pembelajaran berlangsung. Berdasarkan hasil penelitian-penelitian terdahulu seperti pada penelitian Gusti Ayu Nyoman Dewi Satriani, Nyoman Dantes, I Nyoman Jampel (2015, hlm. 9) yang menunjukan bahwa model pembelajaran CORE berpengaruh secara signifikan terhadap kemampuan pemecahan masalah matematika. Juga dalam penelitian Indarti, dkk (2014, hlm. 5-7) menghasilkan kesimpulan bahwa kemampuan memecahkan masalah siswa yang menggunakan model pembelajaran Discovery Learning lebih baik daripada model pembelajaran konvensional. Ketika kedua model pembelajaran ini dibandingkan dengan model pembelajaran konvensional (ekspositori), keduanya sama-sama menghasilkan kesimpulan bahwa kedua model pembelajaran ini lebih baik daripada model pembelajaran konvensional. Namun 
ketika kedua model pembelajaran ini saling dibandingkan hasilnya adalah kemampuan pemecahan masalah matematis siswa SMA yang memperoleh model pembelajaran CORE tidak lebih baik dari kemampuan pemecahan masalah matematis siswa SMA yang memperoleh model pembelajaran Discovery Learning.

Adapun kendala yang dihadapi dalam melaksanakan pembelajaran menggunakan model pembelajaran CORE ini yaitu alokasi waktu yang sangat terbatas. Siswa juga memerlukan waktu yang lebih lama untuk beradaptasi terutama pada tahap Reflecting dimana siswa harus mengingat kembali konsep sebelumnya namun, masih banyak siswa yang lupa sehingga guru harus mengulangnya kembali dan mengurangi keefektifan waktu belajar. Selain itu, dalam pelaksanaannya, siswa perlu dipahamkan terlebih dahulu dengan bimbingan guru secara perlahan mengenai teknis pembelajarannya sebelum penelitian dimulai.

\section{Self-Regulated Learning Siswa}

Data hasil penelitian yang berhasil dikumpulkan adalah data skor pretest dan data skor posttest. Data tersebut kemudian dianalisis untuk mengetahui ketercapaiannya. Pada penelitian ini taraf kepercayaan yang digunakan adalah $95 \%$ atau $\alpha=5 \%$. Secara sekilas skor rata-rata pretest dan postest dapat dilihat dalam tabel 3 berikut.

\section{Tabel 3. Deskripsi Skor Data Self-Regulated Learning}

\begin{tabular}{ccc}
\hline Kelas & $\overline{\boldsymbol{x}}$ Pretest & $\overline{\boldsymbol{x}}$ Posttest \\
\hline Eksperimen 1 & 84,087 & 83,490 \\
Eksperimen 2 & 82,503 & 79,709 \\
\hline
\end{tabular}

Berdasarkan analisis data hasil tes akhir (posttest) yang telah dilakukan, dapat dilihat bahwa skor rata-rata kemampuan pemecahan masalah pada kelas eksperimen 1 yang menggunakan model pembelajaran CORE lebih rendah namun tidak berbeda jauh dibandingkan dengan kelas eksperimen 2 yang menggunakan model pembelajaran Discovery Learning. Data tersebut kemudian diuji normalitas dan homogenitasnya. Hasil analisis menunjukkan bahwa kedua kelas berdistribusi normal dan homogen.

Selanjutnya dilakukan uji kesamaan dua rerata dengan uji-t dua pihak menggunakan Independent Sample T-Test. Hipotesisnya dirumuskan dalam bentuk hipotesis statistik (uji pihak kanan) menurut Sugiyono (2016, hlm. 121) sebagai berikut:

$\mathrm{H}_{0}: \mu_{1} \leq \mu_{2}$

$\mathrm{H}_{\mathrm{a}}: \mu_{1}>\mu_{2}$

Perumusan hipotesis komparatifnya sebagai berikut:

$\mathrm{H}_{0}$ : Self-Regulated Learning siswa yang menggunakan model pembelajaran CORE (Connecting, Organizing, Reflecting and Extending) tidak lebih baik dibandingkan dengan siswa yang menggunakan model pembelajaran Discovery Learning dalam pembelajaran matematika.

$\mathrm{H}_{\mathrm{a}}$ : Self-Regulated Learning siswa yang menggunakan model pembelajaran CORE (Connecting, Organizing, Reflecting and Extending) lebih baik dibandingkan dengan siswa yang menggunakan model pembelajaran Discovery Learning dalam pembelajaran matematika.

Setelah dilakukan pengolahan data, tampilan data dapat dilihat pada Tabel 4.

Tabel 4. Uji-t Self-Regulated Learning

\begin{tabular}{cccc}
\hline & \multicolumn{3}{c}{ t-test for Equality of Means } \\
\cline { 2 - 4 } & $\mathrm{t}$ & $\mathrm{df}$ & Sig. (2-tailed) \\
\hline Equal variances assumed & 1.807 & 62 & .076 \\
\hline
\end{tabular}


Pada Tabel 4 nilai signifikasi 2-tailed $=0,076$. Menurut Uyanto (2006, hlm. 120), "Karena kita melakukan uji hipotesis satu pihak, maka nilai $p$-value (2-tailed) harus dibagi dua", sehingga menjadi $\frac{0,076}{2}=0,038$. Karena $p$-value $=0,038>\alpha=0,05$ maka $\mathrm{H}_{0}$ diterima dan $\mathrm{H}_{\mathrm{a}}$ ditolak. Hal ini juga terlihat pada Gambar 2.

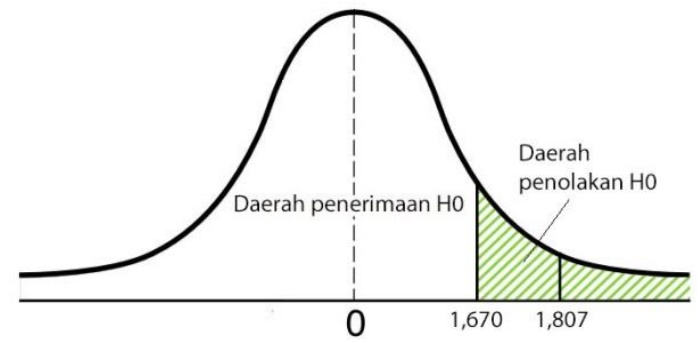

Gambar 2. Uji Satu Pihak Self-Regulated Learning

Pada Gambar 2 dengan nilai $d f=62$ dan taraf kesalahan $(\alpha)$ ditetapkan 5\% terlihat bahwa $t_{\text {hitung }} \geq t_{\text {tabel }}(1,807 \geq 1,670)$, nilai $t_{\text {hitung }}$ berada pada daerah penolakan $\mathrm{H}_{0}$, maka $\mathrm{H}_{0}$ ditolak dan $\mathrm{H}_{\mathrm{a}}$ diterima sehingga dapat disimpulkan bahwa Self-Regulated Learning siswa yang menggunakan model pembelajaran CORE (Connecting, Organizing, Reflecting and Extending) lebih baik dibandingkan dengan siswa yang menggunakan model pembelajaran Discovery Learning dalam pembelajaran matematika.

Hal ini sesuai dengan hipoteis yang disusun oleh peneliti. Selain itu berdasarkan hasil penelitian-penelitian terdahulu seperti pada penelitian Yumiati (2015, hlm. 297) menghasilkan kesimpulan bahwa pencapaian dan peningkatan Self-Regulated Learning siswa dalam pembelajaran CORE lebih baik daripada siswa dalam pembelajaran konvensional. Juga dalam penelitian Fitri Sabina (2014, hlm. 18) yang menghasilkan kesimpulan bahwa terdapat pengaruh peningkatan Self-Regulated Learning siswa yang diajarkan model pembelajaran Discovery Learning dengan pendekatan saintifik. Ketika kedua model pembelajaran ini dibandingkan dengan model pembelajaran konvensional, keduanya sama-sama menghasilkan kesimpulan bahwa kedua model ini lebih baik daripada model konvensional. Namun ketika kedua model ini saling dibandingkan hasilnya adalah Self-Regulated Learning siswa yang menggunakan model pembelajaran CORE (Connecting, Organizing, Reflecting and Extending) lebih baik dibandingkan dengan siswa yang menggunakan model pembelajaran Discovery Learning dalam pembelajaran matematika.

\section{KESIMPULAN}

Berdasarkan penelitian yang dilaksanakan mengenai perbandingan antara penggunaan model pembelajaran CORE dan model pembelajaran Discovery Learning untuk meningkatkan kemampuan pemecahan masalah dan Self-Regulated Learning siswa SMA diperoleh kesimpulan sebagai berikut: (1) Kemampuan pemecahan masalah matematis siswa SMA yang memperoleh model pembelajaran CORE tidak lebih baik dari kemampuan pemecahan masalah matematis siswa SMA yang memperoleh model pembelajaran Discovery Learning. (2) Self-Regulated Learning siswa yang dalam pembelajaran matematikanya menggunakan model pembelajaran CORE lebih baik daripada siswa yang menggunakan model pembelajaran Discovery Learning.

\section{REKOMENDASI}

Berdasarkan hasil penelitian dan hasil kesimpulan yang diperoleh, maka diajukan beberapa rekomendasi yang diharapkan dapat menjadi bahan masukan dalam melaksanakan 
proses pembelajaran. Adapun rekomendasi tersebut adalah sebagai berikut: (1) Berdasarkan hasil penelitian ini, secara keseluruhan model pembelajaran CORE memberikan pengaruh yang lebih baik terhadap Self-Regulated Learning siswa jika dbandingkan dengan menggunakan model pembelajaran Discovery Learning dengan demikian, model pembelajaran CORE sebaiknya digunakan dalam pembelajaran matematika dalam rangka meningkatkan Self-Regulated Learning siswa. (2) Bagi guru yang akan menerapkan model pembelajaran CORE dalam pembelajaran matematika hendaknya mempersiapkan alokasi waktu dan perhatian yang lebih besar terutama pada tahap diskusi kelompok karena pada tahapan ini siswa membutuhkan lebih banyak waktu. (3) Berdasarkan hasil temuan dalam penelitian ini, pada kemampuan pemecahan masalah matematis siswa pada kelas eksperimen 2 dan kelas eksperimen 1 tidak berbeda secara signifikan. Jika penelitian ini dilanjutkan diduga akan terjadi perbedaan hasil pada kemampuan pemecahan masalah matematis. Oleh sebab itu, bagi peneliti selanjutnya direkomendasikan untuk meneliti kemampuan tersebut.

\section{UCAPAN TERIMAKASIH atau CATATAN}

1. Bapak Dr. H. Tatang Mulyana, M. Pd., selaku dosen pembimbing yang selalu bijaksana memberikan bimbingan, nasehat, arahan, serta waktunya selama penelitian ini.

2. Bapak Darta, M. Pd., selaku Ketua Program Studi Pendidikan Matematika di Universitas Pasundan.

3. Bapak Udin Saehudin, S. Pd., M. Pd., selaku kepala SMAN 13 Bandung.

4. Bapak Drs. Lukman Wargadinata, selaku wakasek kurikulum di SMAN 13 Bandung yang telah memberikan izin pelaksanaan penelitian.

5. Bapak Dedi Desrawan, S. Pd., selaku guru mata pelajaran matematika di SMAN 13 Bandung yang telah membantu dalam pelaksanaan penelitian.

6. Ibu Isnaeni Zakiah, S. Pd., M. M. Pd., selaku kepala SMAN 6 Bandung.

7. Siswa-siswi SMAN 13 Bandung dan SMAN 6 Bandung yang tak dapat disebutkan satu persatu yang telah membantu proses kelancaran penyusunan skripsi ini.

\section{REFERENSI}

Andriatna, R. (2012). Meningkatkan Kemampuan Pemecahan Masalah Matematis SMA melalui Menulis Matematika dalam Pembelajaran Berbasis Masalah. Skripsi FMIPA UPI: Tidak Diterbitkan.

Calfee. (2004). Making Thingking Visible, National Science Education Standards. Riverside: University of California.

Depdiknas. (2006). Kurikulum Tingkat SatuanPendidikan. Jakarta: Depdiknas.

Hamalik, O. (2002). Pendidikan Guru Berdasarkan Pendekatan Kompetensi. Jakarta: PT. Bumi Aksara.

Hosnan, M. (2014). Pendekatan Saintifik dan Konseptual dalam Pembelajaran Abad 2. Bogor: Ghalia Indonesia.

Indarti, Suyudi, A., \& Yogihati, C. I. (2014). Pengaruh Model Discovery Learning Terhadap Kemampuan Memecahkan Masalah Siswa Kelas X SMAN 8 Malang. Skripsi Jurusan Fisika Universitas Negeri Malang: Tidak Diterbitkan.

Pintrich. (1990). Motivational and self-regulated learning components of classroom academic performance. Journal of Educational Psychology.

Polya, G. (1981). Mathematical discovery on Understanding. Learning and Teaching Problem Solving. New York: John Willey \& Sons.

Ruseffendi, E. T. (2010). Dasar-dasar Penelitian Pendidikan \& Bidang Non-Eksakta Lainnya. Bandung: Tarsito. 
Sabina, F. (2016). Penerapan Discovery Learning dengan Pendekatan Scientific dalam Meningkatkan Kemampuan Pemahaman Konsep dan Kemampuan Penalaran Matematis serta Dampaknya terhadap Self Regulated Learning Siswa SMP. Thesis Pendidikan Matematika UNPAS: Tidak Diterbitkan.

Sadirman, A. M. (2005). Interaksi dan Motivasi Belajar Mengajar. Jakarta: PT Raja Grafindo Persada.

Satriani, D., Dantes, N., \& Jampel, N. (2015). Pengaruh Penerapan Model CORE Terhadap Kemampuan Pemecahan Masalah Matematika Dengan Kovariabel Penalaran Sistematis Pada Siswa Kelas III Gugus Raden Ajeng Kartini Kecamatan Denpasar Barat. Jurnal Pasca Sarjana Universitas Pendidikan Ganesha, Singaraja, Indonesia. Sugiyono. (2014). Statistika untuk Penelitian. Bandung: Alfabeta.

UNPAS. (2017). Panduan Penulisan Karya Tulis Ilmiah (KTI). Bandung: FKIP UNPAS.

Uyanto, S. S. (2006). Pedoman Analisis Data dengan SPSS. Yogyakarta: Graha Ilmu.

Wahab, A. A. (2007). Metode dan Model-Model Mengajar. Bandung: Alfabeta.

Woolfolk, A. H. (2004). Educational Psychology 9th Edition. USA: Pearson.

Yumiati. (2015). Meningkatkan Kemampuan Berpikir Aljabar, Berpikir Kritis Matematis,dan Self-Regulated Learning Siswa SMP Melalui Pembelajaran CORE (Connecting, Organizing, Reflecting, Extending). Disertasi Pendidikan Matematika UPI Bandung: Tidak Diterbitkan.

Yuniarti, S. (2013). Pengaruh Model CORE Berbasis Kontekstual Terhadap Kemampuan Pemahaman Matematik Siswa. Jurnal PRODI PMT STKIP Siliwangi Bandung, hal.3.

Zimmerman, B. J. (1998). .Developing Self-Fulfilling Cycles of Academic Regulatioan: An Analysis of Exemplary Instructional Models. Dalam D. H. Schunk, \& B. J. Zimmerman, Self-Regulated Learning : From Teaching to Self-Reflective Practice. New York: The Guil. 